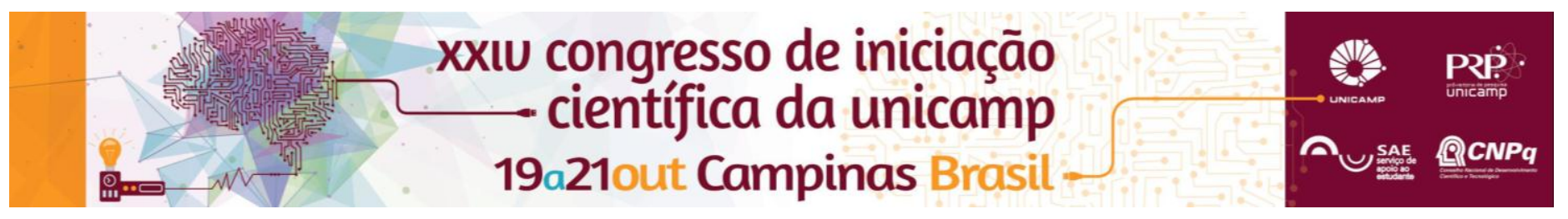

\title{
Avaliação energética de um fogão operando a etanol de cana-de-açúcar
}

\author{
Alex I. Francisco*, Ricardo Baldassin Jr, Luiz A. H. Nogueira.
}

\section{Resumo}

O presente trabalho visou avaliar a performance energética de um fogão portátil operando a etanol. Os experimentos foram conduzidos segundo o protocolo Water Boiling Test (WBT) da Universidade da Califórnia-Berkeley. Os ensaios preliminares consideraram três diferentes níveis de hidratação do etanol $(95 \%, 80 \%$ e $75 \% \mathrm{v} / \mathrm{v})$, duas faixas de potência de aquecimento (alta e média) e dois tipos de panelas (alumínio e barro). Os melhores resultados foram obtidos para o menor nível de hidratação $(95 \% \mathrm{v} / \mathrm{v})$, que apresentou eficiência de $54,7 \%$, potência igual a $0,387 \mathrm{~kW}$, consumo de etanol de $0,363 \mathrm{~kg}$ e tempo de processo de $94 \mathrm{~min}$. De modo geral, verificou-se que o modelo de equipamento estudado é uma alternativa viável para a substituição de fogões a lenha, entretanto seu desempenho pode variar com as condições de uso.

\section{Palavras-chave}

Eficiência, cocção, consumo, potência.

\section{Introdução}

A dependência de biomassa tradicional (lenha) para cocção de alimentos, principalmente nos países africanos, resulta em inúmeros malefícios à saúde, intensa demanda de trabalho e danos ao meio ambiente. A dependência da lenha chega a $80 \%$ em alguns países da Africa Subsaariana ${ }^{1}$, evidenciando a carência de fontes energéticas mais eficientes e modernas.

Como uma das alternativas, propõe-se o uso de fogões a etanol, por se tratar de uma fonte energética eficiente e ambientalmente sustentável.

O objetivo deste trabalho foi avaliar a performance energética de um fogão para uso doméstico operando a etanol de cana-de-açúcar. Especificamente, buscou-se averiguar o desempenho energético do processo de cocção; a influência das diferentes taxas de hidratação do etanol no desempenho energético; a influência do tipo de recipiente usado na cocção (alumínio e barro); e a influência da razão de abertura do orifício do queimador (total e parcial) na performance energética do processo.

Os resultados obtidos serão empregados em análises técnico-econômicas e ambientais voltados ao uso deste tipo fogão em países Africanos.

\section{Resultados e Discussão}

Para os testes de fervura de água, seguindo o protocolo WBT (2,5 litros de água), foram medidas as seguintes variáveis: massa de água evaporada $(\mathbf{k g})$, massa de combustível consumida (kg) e tempo de operação (s).

Inicialmente, o planejamento experimental contemplava 36 ensaios. No entanto, ao longo dos testes verificou-se que: na condição de potência média (abertura parcial do orifício do queimador) a cocção com a panela de barro não foi possível (longo tempo de processo), e para a hidratação de $75 \% \mathrm{v} / \mathrm{v}$ a temperatura de ebulição da água não foi atingida (para ambas as panelas e potências).

Sendo assim, a análise ficou restrita às condições de abertura total do orifício de queima (potência máxima) e uso da panela de alumínio. Os parâmetros energéticos do fogão foram calculados de acordo com relações termodinâmicas, envolvendo as variáveis mensuradas nos ensaios, o poder calorífico inferior $(\mathbf{k J} / \mathbf{k g})$ da mistura combustível e a energia interna da água $(\mathbf{k J} / \mathbf{k g})$.

Tabela 1. Performance do fogão a etanol.

\begin{tabular}{|l|c|c|}
\hline \multicolumn{1}{|c|}{ Hidratação } & $\begin{array}{c}95,0 \% \mathrm{v} / \mathrm{v} \\
\text { etanol }\end{array}$ & $\begin{array}{c}80,0 \% \mathrm{v} / \mathrm{v} \\
\text { etanol }\end{array}$ \\
\hline Eficiência média (\%) & 54,7 & 41,6 \\
\hline Potência média (kW) & 0,387 & 0,229 \\
\hline Consumo energético (MJ) & 2,180 & 1,858 \\
\hline Consumo de combustível (kg) & 0,363 & 0,393 \\
\hline Tempo total (min) & 94 & 137 \\
\hline
\end{tabular}

A partir dos dados preliminares obtidos, observa-se que a eficiência, a potência e o consumo energético decrescem com 0 aumento do teor de água no combustível, sendo tais resultados devido à redução do poder calorífico do combustível. Como reflexo de um combustível mais pobre energeticamente, o tempo total do processo foi $40 \%$ superior para a hidratação $80 \% \mathrm{v} / \mathrm{v}$.

Nas próximas etapas deverão ser experimentadas as hidratações de $90 \% \mathrm{v} / \mathrm{v}$ e $85 \% \mathrm{v} / \mathrm{v}$. A partir dos dados obtidos, os resultados serão avaliados em vista da performance de outros tipos de fogões.

Em se tratando da usabilidade do fogão a etanol, verificou-se uma relativa simplicidade, praticidade e segurança em toda a operação. Entretanto, a impossibilidade de recarga do reservatório de etanol com o fogão em operação (com a outra boca em uso, por exemplo), é uma deficiência do modelo empregado.

\section{Conclusões}

Os resultados parciais permitem concluir que: a hidratação $95 \% \mathrm{v} / \mathrm{v}$ foi a que apresentou os melhores resultados, hidratações inferiores a $75 \% \mathrm{v} / \mathrm{v}$ e o uso de panelas de barro não foram tecnicamente viáveis.

Desta forma, este tipo de fogão pode ser uma alternativa eficiente na substituição de fogões a lenha.

\section{Agradecimentos}

À FAPESP (Processos 2016/01463-2 e 2012/002823) pelo financiamento deste estudo.

\footnotetext{
${ }^{1}$ IEA. World Energy Outlook 2014. International Energy Agency: OECD/IEA, França, p. 726, 2014.
} 